
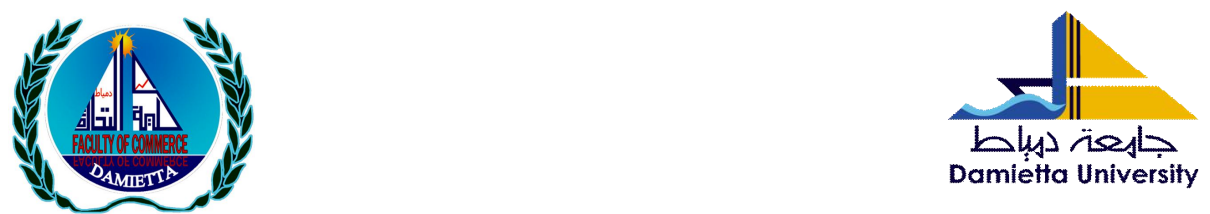

The Relationship between managers' Formal Sources of Power and Open-Book Management practices: An applied study on workers of special centers and units at Mansoura University

\author{
Prepared 6y \\ Dr. Mohamed Rabie Zanaty \\ Youssef \\ Professor of Business Administration \\ and former dean at faculty of Commerce- \\ Tanta University \\ Dr. Hamida Mohamed El- \\ Naggar \\ Professor and head of Business \\ Administration department -Faculty of \\ Donia Mohamed Galal Soliman \\ Administrator of Business Administration \\ Faculty of Commerce- Mansoura University
}

Scientific Journal for Financial and Commercial Studies and Researches (SIFCSR)

Faculty of Commerce - Damietta University

Vol.3, No.1, Part 1., January 2022

APA Citation:

Youssef, M. R.Z.; El- Naggar, Soliman, D. M. G. and (2022). The Relationship between managers' Formal Sources of Power and Open-Book Management practices: An applied study on workers of special centers and units at Mansoura University, Scientific Journal for Financial and Commercial Studies and Research, Faculty of Commerce, Damietta University, 3(1)1.pp.235-284

Website: https://cfdj.journals.ekb.eg/ 
Scientific Journal for Financial and Commercial Studies and Researches

(SJFCSR) Faculty of Commerce - Damietta University

\title{
The Relationship between managers' Formal Sources of Power and Open-Book Management practices: An applied study on workers of special centers and units at Mansoura University
}

Dr. Mohamed Rabie Zanaty Youssef

Dr. Hamida Mohamed El- Naggar

Donia Mohamed Galal Soliman

\begin{abstract}
:
This study aimed to investigate the relationship between Managers' Formal Sources of Power (Legitimate, Reward, and Coercive) and OpenBook Management practices (OBM) (Sharing information, Training, Empowering, and Rewarding) on the workers in special centers and units at Mansoura University. The study employed a deductive approach, and a quantitative research method. A questionnaire was used to collect data from 794 workers (with $88.12 \%$ response rate). A Partial Least Square (Warp-PLS V.7) was applied to test the research hypotheses and show the causal relationships between study variables. research findings showed that there is a significant correlation between managers' formal sources of power and OBM practices, where legitimate and reward powers had significant positive correlations while coercive power had significant negative correlation with OBM practices in special centers and units at Mansoura University. Findings also revealed that managers' formal sources of power had a significant direct impact on OBM practices, where legitimate and reward powers had significant direct positive impacts while coercive power had a significant direct negative impact on OBM practices in special centers and units at Mansoura University. Finally, theoretical and practical implications were presented in addition to future research suggestions.
\end{abstract}


Youssef, M. R.Z.; El- Naggar, Soliman, D. M. G

\section{1) Introduction:}

In recent years, there has been a lot of publicity about Open-Book Management (OBM) and a lot of discussions around it. There are many claims on the potential of OBM in revolutionizing the businesses. Many cases show that OBM if applied correctly and suitably will be beneficial (Maurer, 2001).

Open-Book Management (OBM) is a philosophy pioneered by Jack Stack, represent an approach to running a company in which employees are empowered with decision-making ability. According to John Case; "it is a way of running a company that gets everyone focused on helping the business make money, no more, no less" (Case, 1996).

Hence, OBM is a contemporary methodology. It supports elements such as self-confidence and creativity, promotes independent thinking and an initiative-taking spirit, Moreover, it creates a democratic working environment, all of which are vital to the rapidly changing conditions (Melhem, 2006). Considering the whole approach of OBM to be a powerful aid to "good management".

On the other hand, Power is now frequently examined empirically in the psychological and leadership literature according to the types of power commonly enacted by managers, when types of power are effectively used, and why managers tend to move away from effective shared management in favor of acting in self-interest (Pitesa \& Thau, 2013).

From the previous overview, the researcher concludes that OBM and Power are particularly important in private, non-public companies and in divisions of large public companies where financial and other performance data are not easily or publicly available.

Mansoura university has established a group of special centers and units to help in attaining its mission to contribute in the field of education, training and scientific research, helping the productive and service activity at the local level, participating in the treatment of problems on a scientific basis, and developing the resources of university. So, in order to achieve the mission of these units it needs to have managers with effective sources of power. 
Scientific Journal for Financial and Commercial Studies and Researches

(SJFCSR) Faculty of Commerce - Damietta University

\section{2) Theoretical framework:}

The researcher demonstrated each of the study variable's definitions as follows:

According to (French \& Raven, 1959), Formal sources of power consists of legitimate, reward, and coercive powers. While informal sources of power include expert and referent powers. The researcher demonstrated the study of managers' formal sources of power as they are more comprehensive and also affects in informal power. For example, (Afzalur Rahim et al., 2001) study indicated that legitimate power influenced referent power positively and coercive power negatively, and reward and legitimate powers positively influenced expert power, which in turn, positively influenced referent power. While (Rahim and Psenicka, 1996) study found that coercive power negatively influenced individual outcomes through the mediation of its effects on expert and referent power bases (informal sources of power).

\subsection{Formal Sources of Power:}

Formal sources of power include legitimate power, reward power and coercive power.

\subsubsection{Legitimate power:}

Legitimate power represents the formal hierarchical authority that comes from a position. It is called legitimate because it represents a belief that those holding certain positions have a legitimate right to prescribe behavior, and those reporting to the position have a legitimate obligation to follow (Uhl-bien et al., 2013). According to (Havold, 2009), legitimate power refers to the power conferred by a person's organizational position. This type of power is based on the premise that an organizational leader has the authority and the right to give orders based on their position within the organization. Also, legitimate power is the power based on the employees' belief that their manager has the legitimate right to manage the organization (French \& Raven, 1959).

\subsubsection{Reward power:}

Reward power comes from the ability to administer outcomes that have positive valence (i.e., provide positive rewards) and remove or 
Youssef, M. R.Z.; El- Naggar, Soliman, D. M. G

decrease outcomes that have negative valence (i.e., remove negative rewards). Examples of rewards include money, promotions, kudos, enriched jobs, or not assigning unpleasant task duties or undesirable work schedules (Uhl-bien et al., 2013). According to (Alapo, 2018), reward power based on the ability of the manager to reward the employees. As for (French \& Raven, 1959), reward power is defined as the power of praise, pay raise, giving bonuses. Both tangible and intangible rewards can be given or withheld to mobilize this power. While (Havold, 2009) defined reward power as the ability to get the work done through others on basis of one's power to grant rewards. Such rewards could be tangible such as monetary, or intangible such as job promotion.

\subsubsection{Coercive power:}

Coercive Power involves the use of threat or punishment. It stems from the expectation that one will be punished if he or she fails to conform to the influence attempt. For example, coercive power can involve the threat that one will be transferred, demoted, or fired if they do not act as desired (Uhl-bien et al., 2013). As for ( Havold, 2009), coercive power is the power of punishing the subordinates; there are many different ways of doing this, ranging from verbal lashing to reduce pay or firing the individual. Also (French \& Raven, 1959) defined coercive power as a Power based on the perception that the manager can punish the employees if they do not confirm to their manager's influence attempt. Finally, (Merchant, 2013) said, it is the ability to influence others by using threats, punishments or sanctions; in an organizational setting this source of power can be used in order to control the employees and ensure that their actions are congruent with organizational policies.

Therefore, this study will adopt (French \& Raven, 1959) definitions of formal power sources because it covers all the other points.

\subsection{Open-Book Management practices (OBMp):}

Open-Book Management (OBM) is a philosophy pioneered by Jack Stack, represent an approach to running a company in which employees are empowered with decision-making ability. According to John Case; "it is a way of running a company that gets everyone focused on helping the business make money, no more, no less" (Case, 1995). Several studies indicated that open book in management it means "distributing and 
Scientific Journal for Financial and Commercial Studies and Researches

(SJFCSR) Faculty of Commerce - Damietta University

sharing financial information, industry processes, quality reports, customer service reports, between staff in an organization." Hence, according to (Melhem, 2006), OBM means "disclosure of what happens in the organization for employees, where management is working in a glass house open to all workers, there are no secrets or private information but all workers in the organization are parents in information.

In terms of (Kinney \& Raiborn, 2008), OBM is; "a philosophy about increasing a firm's performance by involving all workers and by ensuring that all workers have access to operational and financial information necessary to achieve performance improvement". Similarly, (The Economic Times, 2016) defined Open-Book Management practices (OBMp) as "empowering every employee of an organization with required knowledge about the processes, adequate training and powers to make decisions which would help them in running a business. It is all about team work and moving forward collectively".

The study will adopt the definition viewed by (Kinney \& Raiborn, 2008) because it covers all practices of OBM.

Many researchers showed that OBM consists of four basic practices illustrated as follows; (Ismael, 2018), (C.Dopico et al, 2018), (Al-Sha'ar, 2016):

-Employee empowerment.

-Sharing information.

-Teaching and training programs.

-Reward or incentive system.

Other researchers illustrated OBM practices as; (Al-Sha'ar, 2016), (Aggarwal and Simkins, 2001):

-Share: sharing financial indexes information.

-Teach: teaching all of the employees how to read and understand the financial indexes variables and the reports related to the costs.

-Empower: empowering the employees to make the necessary change (teaching, training, qualifying, and authority delegation). 
Youssef, M. R.Z.; El- Naggar, Soliman, D. M. G

-Pay: paying the employees fair wages and salaries and share of revenues and incentives in the form of shares to the employees. Also, researchers such as; (Nikzad \& Maryam, 2011), (Aggarwal \& Simkins, 2001) showed the practices as follows:

-Get information out there

-Teach the basics of financial and performance measures

-Empower people to make decisions based on what they know

-Make sure everyone shares directly in the firm's success According to previous practices, the researcher will depend on (AlSha'ar, 2016) OBM practices as it includes sharing information, training, empowering and rewarding.

\section{Literature Review:}

Through the following, the researcher demonstrated the extant literature related to the study variables of managers' formal sources of power and OBM practices:

\subsection{Formal Sources of Power;}

Empirical research conducted by (Elangovan and Lin Xie, 2000) revealed that there is positive association between subordinate's satisfaction and reward, legitimate and referent power bases. Furthermore, (Elangovan and Lin Xie, 2000) indicated that perceived legitimate, reward, expert and referent power of a supervisor would be positively related to subordinates' work motivation, while perceived coercive power of the supervisor would be negatively related to subordinates' work motivation. Results also showed that perceived legitimate power and coercive power of the supervisor were major predictors of subordinate stress, while perceived legitimate power and reward power were important predictors of employee motivation. Further, perceived coercive, reward and legitimate powers were all significant predictors of subordinate commitment. Hence, perceived coercive power was negatively associated with subordinate satisfaction.

Moreover, according to (Turman, 2006), a significant main effect for athlete playing status, whereby starters perceived higher levels of reward power use when compared to non-starters. Likewise, the results 
Scientific Journal for Financial and Commercial Studies and Researches

(SJFCSR) Faculty of Commerce - Damietta University

indicated that coaches' reward and expert power use were the only significant predictors of athlete satisfaction levels. Similarly, (Greve and Mitsuhashi, 2007) argued that a concentration of power among the top management teams (TMT) increases the likelihood of strategic change in firms.

Similarly, (Malhotra et al., 2007) study found that giving reward to employees and using reward power suitably are important factors to reinforce psychological contracts among the employees and management. Also, (Kantek and Gezer, 2010) study showed that faculty members used coercive power most often and used reward power least often. In addition, in the examination of relationships between power bases, it was determined that there were positive correlations between legitimate, referent, reward and expert power, but coercive power was only positively correlated with legitimate power.

According to (Randolph and Kemery, 2011), power is reasonable to believe that employees' cognitive assessment of their manager's use of power will influence their intentions (to perform, to stay with and endorse their organization, to engage in organizational citizenship behaviors, and to use discretionary effort). Additionally, Hard forms of power (e.g., coercive, reward, and legitimate) are related to greater burnout, absenteeism, and lower productivity and self-confidence.

Other study applied by (Zameni et al., 2012) revealed that the use of coercive power base by leaders has negative impacts on the level of commitment and job satisfaction, while other sources of power had a positive impact on the level of commitment and job satisfaction. Moreover, (Meng et al., 2014) study analysis indicated legitimate power and expert power were positively related to attitudinal compliance; legitimate power, coercive power and expert power had positive correlations with group members' behavioral compliance; and referent power, reward power, and expert power were positively associated with group members' satisfaction with supervision. They also found that referent, expert and reward powers used by leaders have a positive relationship with satisfaction.

A study tested by (Riasi and Asadzadeh, 2015) found positive relationship between principals' reward power and accommodating 
Youssef, M. R.Z.; El- Naggar, Soliman, D. M. G

conflict management style. In addition, A study by (Teimouri et al., 2015) explored Two important findings. First, there was a positive and significant relationship between formal and informal sources of power with affective commitment. Second, reward power had the highest effect and coercive power had the lowest effect on employees' affective commitment.

According to (Zigarmi et al., 2015), coercive power strongly correlates with negative affect and increases the possibility of reduced intentions to perform and intentions to use organizational citizenship behaviors from their employees. A second consideration is that when leaders increase their use of legitimate power, they reduce their employees' positive feelings and lessen the possibility of all five of the intentions occurring from their followers.

Similarly, another study by (Riasi and Asadzadeh, 2016) revealed that principals' coercive power has a positive relationship with avoiding and competing conflict management styles. It was also found that principals' legitimate power is positively related to accommodating and collaborating conflict management styles. This finding proved that reward power and legitimate power can be used together in order to facilitate the use of accommodating conflict management style.

Moreover, (Walls and Berrone, 2017) study found that any source of CEO power, whether informal or formal, is a good catalyst for transforming shareholder activism into corporate greening. Also, (Yoon and Farmer, 2018) research showed that positional power - Legitimate, reward and coercive power - was positively associated with incivility. And that Coercive power was a stronger predictor of incivility for individuals with high humility than those with low humility. Hence, (Håvold and Håvold, 2019) research concluded that legitimate and reward power had a positive influence on trust, while coercive power had a negative influence on trust.

\subsection{OBM and its practices:}

A study by (Schuster et al., 1996) reported two major aspects of OBM, which were to motivate employees and to ensure their involvement in addition to financial performance enhancement. Similarly, according to (Negron, 1997) Trust is a key component of 
Scientific Journal for Financial and Commercial Studies and Researches

(SJFCSR) Faculty of Commerce - Damietta University

OBM. So, the level of trust within the company increases when information is out in the open. They also say that a key element in the successful implementation of OBM is understanding the boundaries of the decision-making process, as empowering the workforce and pushing decision-making down is a natural outgrowth of flattening work organizations.

However, study by (Aggarwal and Simkins, 2001) revealed that OBM has a positive relationship with optimizing the deployment of human capital. they viewed OBM as the "missing link" in making many managerial methods more effective over the long run. They also cleared that OBM is positively correlated to the total performance in both public and private sector. Whereas a study of 50 open-book organizations by the National Center for Employee Ownership and Inc. magazine point out that open-book organizations grew $1.66 \%$ faster than their competitors according to (Kidwell and Scherer, 2001).

Hence, In the study of (Al-Mekhalfi, 2008), the result showed that Open Book management helps in formulating the relative atmosphere for innovations and development and also found that OBM increases occupational satisfaction of teachers. Whereas a study (Buhler, 2010) confirms that OBM has been one of the latest management techniques and states that OBM tends to focus more on reasons. Going beyond the more traditional management methods, OBM helps employees understand why they should be concerned about their business' performance. It helps employees make sense of what is happening and care about the success of their organization.

In addition, in terms of (Broughton and Thomas, 2012) study, ; the results showed that OBM impact on improving profitability and productivity, also, organizations have realized other benefits from the practice. These benefits include improved employee satisfaction, engagement, retention, motivation, innovation and corporate sustainability. Moreover, the results of (Singh et al, 2012) study suggested that industries can better leverage the use of open books for joint problem solving, equitable profit sharing and supplier selection. In addition, that study highlighted that an OBM policy can have broader applicability than recognized by many past studies and indicates that it can serve purposes of strategic decision-making and It can also be an 
Youssef, M. R.Z.; El- Naggar, Soliman, D. M. G

integrated part of a buyer's risk reduction strategy. Also, (Nikzad and Maryam, 2012) research showed that there is a positive relationship between Open Book Management and trust. It also showed that Open Book Management had a significant and positive effect on the percentage of money given as loans to total savings of the branch. On the other hand, Open Book Management had a significant and positive effect on the averages of savings taken by the branch. At last, the result as whole showed that Trust and financial performance of the branches that have the high OBM is more than branches with low OBM just for psychological support is different.

Hence, the study by (Salem et al., 2012) showed that enabling flow of information and communication and the management's greater adoption of the delegation policy are important steps to activate the OBM approach in the management performance of technical secondary schools. Also, A recent study by (Al-Mutairi, 2013) indicated that there is a statistically significant relationship between the application of OBM and increasing job satisfaction of workers.

On the other hand, (Al-Sha'ar, 2016) study reached a set of results including: there are roles with statistically significance for paying the wages and the incentives on achieving differentiation in the business organizations. There are differences with open book management and its variables (Sharing information, Teaching, empowering and paying the employees) on differentiation in the organizations attribute to gender, scientific qualification and practical experience variables.

Also, the relationship between OBM and employee job performance was investigated by (Agbaeze \& Nnaji, 2017) and found a positive effect of OBM on employee performance. Moreover, (Abdulkarim Alkhamis, 2018) study showed positive as well as significant effects of employee training, empowerment and participation on employee job satisfaction and customer satisfaction. The results further pointed out that employee job performance mediated the effect of open book management dimensions on customer satisfaction.

In addition, A study by (Al-Khatib, 2018) revealed that OBM practices (Sharing information, training employees, empowering and rewarding employees) moderate the impact of strategic awareness on 
Scientific Journal for Financial and Commercial Studies and Researches

(SJFCSR) Faculty of Commerce - Damietta University

strategic risk in fuel distributor companies for competitor strength risks, and customer priority shift risks. And increase the impact of strategic awareness on strategic risk. Whereas (Ismael, 2018) study revealed the most important obstacle to applying OBM approach at Bibliotheca Alexandrina, namely the use of traditional methods in management and planning, prevalence of personal interests over public ones, and the dominance of bureaucracy in different departments of the library and absence of disclosure, transparency and empowerment strategies. On the other hand, some strengths in the application of OBM approach at Bibliotheca Alexandrina are visible; for example, information issued by management is precise and clear, and the library provides information to the outside community immediately.

\subsection{The relationship between power and practices of $O B M$ :}

According to the readings of the researcher, there were no studies for the relationship between formal sources of power and OBM as a total, but there were some studies indicated the relationship between some sources of formal power and one or more practice of OBM such as: (Ivar \& Havold, 2018) research indicated that legitimate power influenced trust directly and motivation through trust. also, Reward power had a very strong influence on both trust and motivation.

Furthermore, (Elangovan and Xie, 2000) revealed that perceived legitimate and reward power of a supervisor would be positively related to subordinates' work motivation, while perceived coercive power of the supervisor would be negatively related to subordinates' work motivation.

In addition, Hard forms of power (e.g., coercive, reward, and legitimate) were related to greater burnout, absenteeism, and lower productivity and self-confidence (Elias, 2008; Randolph \& Kemery, 2011).

\section{Comments on Previous Studies:}

According to what has been mentioned before in the previous studies, it has been noted that:

- The studies have highlighted the importance of formal power and open-book management practices and their influences on the organizational and employee performance. 
Youssef, M. R.Z.; El- Naggar, Soliman, D. M. G

- To my best, no previous studies investigated the relationship between formal sources of power and open-book management. and that is considered as the research gap.

- The present study is highly needed in the current era due to increased unethical behaviors and level of corruption.

\section{Research Problem:}

the researcher investigated 30 employees from special centers and units at Mansoura university as follows: (Hoteling and conference center 10, Childhood center 10, Transportation unit 5, ESP 5), the researcher asked a group of questions concerned with formal sources of power and OBM practices depending on literature review and the responses of the sample indicated the following phenomena:

4.1. Shortage in the information shared between managers and their followers.

4.2. Low levels of participation with employees in decision-making.

4.3. lack of interaction and teamwork skills between employees.

4.4. lack in practicing formal sources of power (legitimate, reward and coercive power) in order to manage the units' affairs.

4.5. Information shared by managers suffered from accuracy and integrity.

4.6. Deficiency in suppling feedback about employees' performance.

4.7. The true lack of independence of managers at special centers and units in taking decisions to conduct financial or administrative affairs of their own centers or units.

4.8. Negligence in training and learning programs needed for improving employees' performance.

4.9. Prevalence of climates of non-trust between managers and employees.

4.10. Lack of authority given to employees.

4.11. On the other hand, table (1) shows Average net profits and losses at some special centers and units for the last Three years (20172018-2019); 
Scientific Journal for Financial and Commercial Studies and Researches

(SJFCSR) Faculty of Commerce - Damietta University

Table No. (1) Average net profits and losses at some special centers and units for the last Three years (2017-2018-2019)

\begin{tabular}{|c|c|c|c|c|}
\hline \multirow{2}{*}{$\mathrm{S}$} & \multirow{2}{*}{$\begin{array}{c}\text { Special centers and } \\
\text { units }\end{array}$} & $\begin{array}{c}|c| \\
\text { Average revenues and } \\
\text { expenditures for (2017-2018-2019) }\end{array}$ & $\begin{array}{c}\text { Tverage net } \\
\text { profit (Loss) }\end{array}$ \\
\cline { 3 - 5 } & Total revenues & $\begin{array}{c}\text { Total } \\
\text { expenditures }\end{array}$ & \\
\hline 1 & $\begin{array}{c}\text { Hoteling and } \\
\text { conference unit }\end{array}$ & 1017082 & 1105335 & $(88253)$ \\
\hline 2 & Childhood unit & 525342 & 524703 & 639 \\
\hline 3 & Transportation unit & 719281 & 1140130 & $(420849)$ \\
\hline 4 & ESP Center & 1995205 & 1154830 & 840375 \\
\hline 5 & $\begin{array}{c}\text { Mathematical } \\
\text { Scientific center }\end{array}$ & 4140070 & 3023583 & 1116487 \\
\hline 6 & Nile Club & 2628393 & 2224456 & 403937 \\
\hline 7 & $\begin{array}{c}\text { Performance } \\
\text { Development Center }\end{array}$ & 1057480 & 724230 & 333250 \\
\hline 8 & Quality Assurance & 751325 & 430839 & 320486 \\
\hline 9 & Olympic village & 4572892 & 899938 & 3672954 \\
\hline
\end{tabular}

Source: made by the researcher.

The previous table identified losses in some special centers and units and showed others attained low profits, which are contrary to their inception.

In light of past phenomena, the researcher found that there are deficiencies in applying OBM practices that are necessary to improve performance at Mansoura university centers and units. These problems can be explained in the following questions:

A. What is the correlation between Formal sources of power and OBM practices?

B- What is the impact of Formal sources of power on OBM practices?

\section{Research Goals:}

This research aimed to:

5.1. Determining the correlation between formal sources of power and OBM practices.

5.2. Explaining the impact of formal sources of power on OBM practices. 
Youssef, M. R.Z.; El- Naggar, Soliman, D. M. G

\section{Research Importance:}

The importance of this research appeared at the Scientific and Practical levels as follows:

\section{A. At Scientific level:}

A.1. This research helps to fill the gap related to previous studies that can be found by studying the relationship between managers formal sources of power and OBM practices in special centers and units at Mansoura University.

A.2. This research is dealing with two contemporary topics in today's workplace, which are managers formal sources of power and OBM practices, and will contribute to fine-tuning of these topics' literature.

A.3. The researcher tried to aggregate the most important dimensions of formal sources of power that affect OBM practices.

\section{B. At Practical level:}

B.1. Assisting the managers of special centers and units in developing formal sources of power.

B.2. Providing an appropriate working environment to improve performance and increase interactions between individuals.

B.3. Helping special centers and units in developing criteria for selecting and recruiting the managers, forming work-forces, improving negotiating skills and leadership capacity.

B.4. Contributing in changing and developing the relationship between special centers and units and assisting them in dealing with the community.

B.5. Creating a climate of trust between management levels from one hand, and between them and the whole community from another hand.

B.6. Helping special centers and units to obtain support from senior managers and the surrounding environment, by improving its performance indicators. 
Scientific Journal for Financial and Commercial Studies and Researches (SJFCSR) Faculty of Commerce - Damietta University

B.7. Increasing self-financing resources of Mansoura university by improving the efficiency of special centers and units.

B.8. Linking the activities and products provided by special centers and units with local community needs through increasing managers capacity to negotiate and interact with the community.

B.9. Designing effective training programs for both managers and employees of special centers and units to improve leadership skills and financial decision-making.

B.10. Acquiring the capacity to influence the performance of subordinates and developing the methods of evaluating performance.

\section{Research Hypotheses:}

According to the previous literature review, research objectives, research problem, the research hypotheses and sub-hypotheses are to be established as follows:

H1. Formal sources of power have a significant correlation with OBM practices. This hypothesis is divided into the following subhypotheses;

H1.1. Legitimate power has a significant positive correlation with OBM practices.

H1.2. Reward power has a significant positive correlation with OBM practices.

H1.3. Coercive power has a significant negative correlation with OBM practices.

H2. Formal sources of power have a significant direct impact on OBM practices. This hypothesis is divided into the following subhypotheses;

H2.1. Legitimate power has a significant direct positive impact on OBM practices.

H2.2. Reward power has a significant direct positive impact on OBM practices. 
Youssef, M. R.Z.; El- Naggar, Soliman, D. M. G

H2.3. Coercive power has a significant direct negative impact on OBM practices.

\section{Research Methodology:}

\subsection{Research Variables and Measures:}

Table No (2) shows independent and dependent variables of the research and measuring sources for each variable.

\section{Table (2) Research Variables and Measures}

\begin{tabular}{|c|c|}
\hline \multicolumn{2}{|c|}{ Independent Variable } \\
\hline $\begin{array}{l}\text { Sources of Formal } \\
\text { Power }\end{array}$ & $\begin{array}{l}\text { It was measured using a set of statements related to: } \\
\text { • Legitimate power } \\
\text { • Reward power } \\
\text { - Coercive power } \\
\text { Items adopted from: } \\
\text { (Hinkin and Schriesheim, 1989), } \\
\text { (French et al., 1959), } \\
\text { (Håvold and Håvold, 2019). }\end{array}$ \\
\hline \multicolumn{2}{|l|}{ Dependent Variable } \\
\hline $\begin{array}{l}\text { Open-Book } \\
\text { Management } \\
\text { practices }\end{array}$ & $\begin{array}{l}\text { It was measured using a set of statements related to: } \\
\text { - Sharing information } \\
\text { - Training employees } \\
\text { - Empowering employees } \\
\text { - Rewarding employees } \\
\text { Items adopted from (Aggarwal and Simkins, 2001), } \\
\text { (Nikzad and Maryam, 2012), (Abdulkarim } \\
\text { Alkhamis, 2018). }\end{array}$ \\
\hline
\end{tabular}


Scientific Journal for Financial and Commercial Studies and Researches

(SJFCSR) Faculty of Commerce - Damietta University

\subsection{Conceptual Framework of the research:}

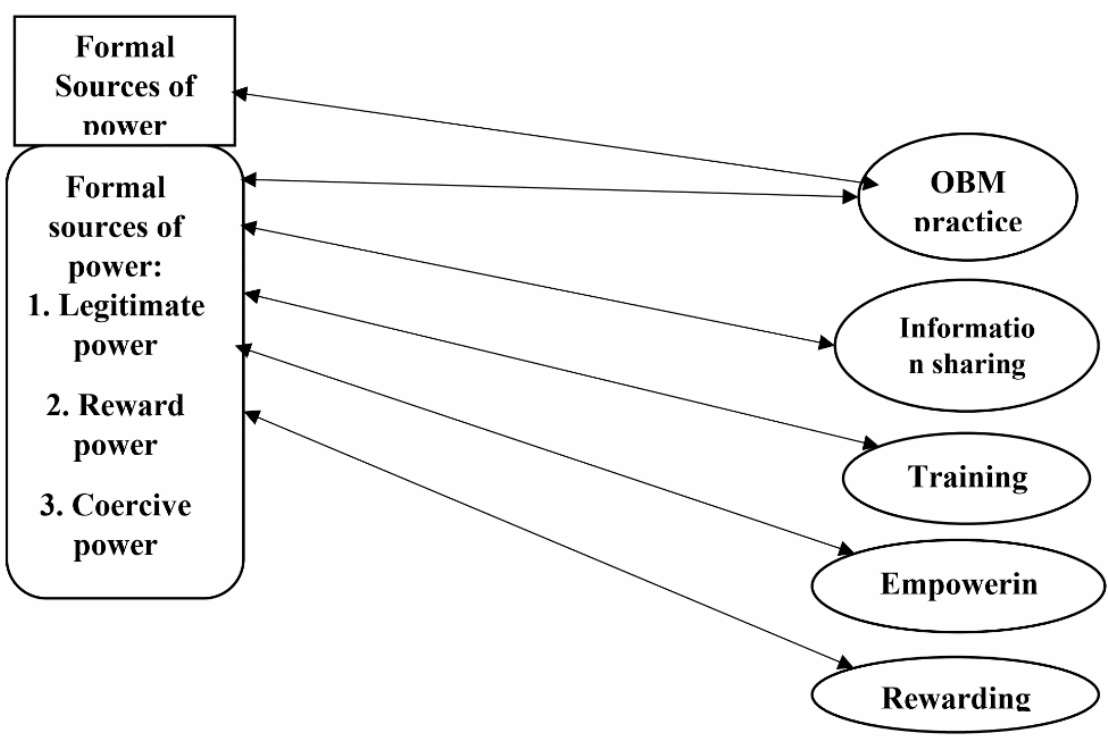

Figure (1.1) the proposed model for the study.

Source: Made by the researcher.

Figure (1.1) illustrates the proposed relationships between research variables.

\subsection{Research Population Description:}

The population of this study consists of permanent employees in 25 special centers and units at Mansoura university. According to (Saunders et al., 2015), if the entire population can be targeted then no need to take sample. Consequently, this study collects census data without sampling.

The total number of this population is 901 members. The Total number of employees in each center and unit, number of respondents and response rate is represented using descriptive statistics as shown in table (3): 
Youssef, M. R.Z.; El- Naggar, Soliman, D. M. G

Table (3) Special centers and units, total number of employees, respondents and response rate.

\begin{tabular}{|c|c|c|c|c|}
\hline & Special centers and units & $\begin{array}{l}\text { Number of } \\
\text { employees }\end{array}$ & Respondents & $\begin{array}{c}\text { \% of } \\
\text { response }\end{array}$ \\
\hline 1 & Mathematical Scientific center & 53 & 48 & 90.6 \\
\hline 2 & Printing center & 50 & 45 & 90 \\
\hline 3 & Childhood Developing center & 43 & 39 & 90.7 \\
\hline 4 & Nile Club & 52 & 49 & 94.2 \\
\hline 5 & Performance Development Center & 17 & 17 & 100 \\
\hline 6 & Transportation unit & 33 & 28 & 84.8 \\
\hline 7 & Olympic village & 34 & 34 & 100 \\
\hline 8 & Books Support Division & 21 & 16 & 76.2 \\
\hline 9 & Communication and Information Center & 56 & 52 & 92.8 \\
\hline 10 & Administrative Training Center & 13 & 11 & 84.6 \\
\hline 11 & Students and Educational Services & 12 & 10 & 83.3 \\
\hline 12 & ESP Center & 33 & 28 & 84.8 \\
\hline 13 & Public Service Center & 19 & 16 & 84.2 \\
\hline 14 & $\begin{array}{l}\text { Agricultural research and } \\
\text { experimenting center }\end{array}$ & 130 & 105 & 80.8 \\
\hline 15 & Hoteling and conference unit & 58 & 55 & 94.8 \\
\hline 16 & Ramada Hotel & 25 & 25 & 100 \\
\hline 17 & Education Technology Center & 15 & 11 & 73.3 \\
\hline 18 & Scientific and lab services & 143 & 123 & 86 \\
\hline 19 & Workers Treatment unit & 17 & 14 & 82.4 \\
\hline 20 & University Homicide & 13 & 13 & 100 \\
\hline 21 & Marketing University Services Center & 7 & 7 & 100 \\
\hline 22 & $\begin{array}{l}\text { Research and Engineering } \\
\text { Consulting Center }\end{array}$ & 35 & 33 & 94.3 \\
\hline 23 & Legal Studies and Consultation Center & 6 & 4 & 66.7 \\
\hline 24 & $\begin{array}{l}\text { Educational and Social Services and } \\
\text { Research center }\end{array}$ & 9 & 6 & 66.7 \\
\hline \multirow[t]{2}{*}{25} & $\begin{array}{l}\text { Services and Activities center in } \\
\text { university cities }\end{array}$ & 7 & 5 & 71.4 \\
\hline & Total & 901 & 794 & 88.2 \\
\hline
\end{tabular}

Source: made by the researcher.

\subsection{Data Collection Procedures:}

The following two techniques were used to collect data: 
Scientific Journal for Financial and Commercial Studies and Researches

(SJFCSR) Faculty of Commerce - Damietta University

\section{A- Office Technique:}

This technique aims at collecting secondary data from sources such as books references, reports, periodicals and previous studies that are related to research variables (Sources of formal power and OBM Practices) for constructing the theoretical framework of the study.

\section{B- Field Technique:}

This technique aims at collecting primary data by using questionnaire prepared for the purpose of the current study. This questionnaire will be directed to the population selected from employees at Mansoura university special centers and units.

\subsection{Measurements:}

Following the efforts that made above, the researcher developed 45 items to measure the constructs of this study, 15 items were used to measure formal sources of power assessed using the 15-item Bases of Social Power scale (Hinkin and Schriesheim, 1989). This is a wellvalidated other-report measure based on (French et al., 1959) concept of bases of formal power and includes three dimensions: legitimate, reward, and coercive power. Moreover, every dimension includes 5 questions. On the other hand, 20 items were used to measure OBM practices,

since OBM in this research was measured based on Four practices: sharing information, employee training, employee empowerment, and employee rewarding system (Aggarwal and Simkins, 2001; Nikzad and Maryam, 2012) and each practice included 5 questions.

A Likert Scale ranging from 1 to 5 were used to measure the respondent's opinions in which 5= "Totally agree" and 1= "Totally disagree".

\subsection{Questionnaire Design:}

In order to collect the required data properly through questionnaires, it is recommended to carry out pilot testing for that questionnaire (Saunders et al., 2015). There are two main goals for performing pilot testing. First, to guarantee that the questionnaire does not contain any unrelated, irrelevant or unclear questions and its design is appropriate and easy to read. Second, to assess whether the questionnaire 
Youssef, M. R.Z.; El- Naggar, Soliman, D. M. G

is measuring what it is intended to measure, and it provides consistent responses(Saunders et al., 2015). To fulfill these two goals, the research checks the questionnaire validity and reliability through the pilot test.

\subsubsection{Research Validity:}

Validity is considered to be the most significant characteristic of questionnaire. It refers to the questionnaire ability to measure what it is intended to measure and how well it is developed, in other words, validity is concerned with the accuracy of a variable measurement (Heale and Twycross, 2015).

First, Content validity is concerned with the degree of relevance and representativeness of the questionnaire items (Rossiter, 2008). To verify the questionnaire's content validity, the questionnaire was directed to ${ }^{*} 9^{1}$ academics in Faculty of Commerce Mansoura University specialized in both marketing and HR fields. The given comments and recommendations regarding the clarity, understandability, and representation of the sentences were utilized by the researcher to reshape the questionnaire form.

Second, Translation of Questionnaire; As the original instrument items that construct the questionnaire are written in English and the target population main language is Arabic. Hence, it is a must to translate the questionnaire to the respondents' main language. Consequently, the researcher translated the questionnaire and then presented the translated questionnaire to a certified translator to assure that the translation is correct and deliver the intended meaning. This procedure is recommended to enhance questionnaire validity. The final version of the questionnaire is shown in Appendix (A).

- ${ }^{1}$ Dr. Abdel Mohsen Abdel Mohsen Gouda, Professor of HR.

- Dr. Abdel Qader Mohamed Abdel Qader, Professor of Marketing.

- Dr. Abdel Hakim Ahmed Nagm, Professor of HR.

- Dr. Talaat Asa'ad Abdelhamid, Professor of Marketing.

- Dr. Wefki Al-Metwaly Al-Emam, Professor of Marketing.

- Dr. Ali Younis Ibrahim, Professor of HR.

- Dr. Mona Mohamed Sayed, Professor of HR.

- Dr. Gad Elrab, Professor of HR.

- Dr. Mamdouh Zaki, Professor of HR 
Scientific Journal for Financial and Commercial Studies and Researches (SJFCSR) Faculty of Commerce - Damietta University

Third, the questionnaire was pilot tested among some employees working at special centers and units at Mansoura university (13 employees), they were asked to answer the questions and then to carefully review all items from critical perspective to seek out problems such as ambiguity or redundancy, the results of pre-test suggested that there was a little need for revision, in addition, none of the respondents involved in the pre-test indicated any difficulty in interpreting the items presented.

\subsubsection{Reliability Analysis and Discriminant Validity:}

Reliability of scales was evaluated using Cronbach's Alpha Test which measures the internal consistency in order to match results across and between items located in the same instrument, Cronbach's Alpha Coefficient is an acceptable measure to evaluate scale reliability. Alpha should be at least 0.7 to realize internal reliability. On the other hand, Discriminant validity refers to the extent to which each variable is distinct from other variables (Hair et al., 2019). It is measured using the square root of Alpha Cronbach. The value of each discriminant validity should be greater than its' correlation with other variables shown in Correlation Matrix. table (4) shows the results of Reliability Analysis and Discriminant Validity as follows:

Table (4) Reliability Analysis: Cronbach's Alpha Coefficients \& Discriminant Validity

\begin{tabular}{|l|c|c|c|}
\hline \multicolumn{1}{|c|}{ Research Variables } & $\begin{array}{c}\text { Number of } \\
\text { items }\end{array}$ & $\begin{array}{c}\text { Cronbach's } \\
\text { alpha }\end{array}$ & $\begin{array}{c}\text { Discriminant } \\
\text { Validity }\end{array}$ \\
\hline Independent (Sources of formal power) \\
\hline LEGP & 5 & 0.885 & 0.941 \\
\hline REWP & 5 & 0.842 & 0.918 \\
\hline COEP & 5 & 0.821 & 0.906 \\
\hline Dependent (OBM) & \multicolumn{5}{|l}{} \\
\hline SHAR & 5 & 0.904 & 0.951 \\
\hline TRAI & 5 & 0.912 & 0.955 \\
\hline EMPO & 5 & 0.863 & 0.929 \\
\hline REWA & 5 & 0.892 & 0.944 \\
\hline
\end{tabular}

Source: statistical analysis output. 
Youssef, M. R.Z.; El- Naggar, Soliman, D. M. G

As shown in table (4), The highest Alpha coefficient is 0.912 and lowest coefficient is 0.821 . So, coefficients of Cronbach's Alpha were greater than 0.7 , Hence, internal reliability criterion for the study variables is satisfied. Furthermore, as table (1-3) shows, each Discriminant Validity is higher than its' correlation with other constructs. Therefore, results confirm that discriminant validity rule is satisfied. The following scales' items will be statistically analyzed using Wrap-PLS software program and none will be eliminated.

\subsection{Research Variables codes and their questionnaire items:}

Table (5) indicates the codes of research variables and their corresponding questionnaire items as follows:

Table (5), Research Variables Codes and its related items

\begin{tabular}{|c|c|c|}
\hline Research Variables & Codes & Questionnaire Questions \\
\hline \multicolumn{3}{|c|}{ Independent Variables "Formal Sources of power" } \\
\hline$\rightarrow$ Legitimate power & LEGP & $1 \rightarrow 5$ \\
\hline$\rightarrow$ Reward power & REWP & $6 \rightarrow 10$ \\
\hline$\rightarrow$ Coercive power & COEP & $11 \rightarrow 15$ \\
\hline \multicolumn{3}{|c|}{ Dependent Variable “OBM" } \\
\hline$\rightarrow$ Sharing information & SHAR & $16 \rightarrow 20$ \\
\hline$\rightarrow$ Training employees & TRAI & $21 \rightarrow 25$ \\
\hline$\rightarrow$ Empowering employees & EMPO & $26 \rightarrow 30$ \\
\hline$\rightarrow$ Rewarding employees & REWA & $31 \rightarrow 35$ \\
\hline
\end{tabular}

Source: Made by the researcher

\section{Tools of Statistical Analysis:}

The following are the statistical techniques that are used for analyzing research data:

- Alpha Cronbach Test, one of the most commonly used tests in the field of management research to verify the reliability of the measures related to research variables. This statistical technique focuses on the degree of internal consistency between items that make up each variable. 
Scientific Journal for Financial and Commercial Studies and Researches

(SJFCSR) Faculty of Commerce - Damietta University

- Multi- Correlation, used to test the first hypothesis.

- Partial Least Squares- Structural Equation Model (PLS-SEM), The gathered data is analyzed using (PLS-SEM) applied through WarpPLS6 software for statistical analysis. Different from the first generation (linear regression), PLS-SEM is one of the most commonly used techniques to perform path analysis in various fields including human resource management (Hair et al., 2019), it also allows complicated analysis by testing the relationships among multiple independent and dependent variables (Gerbing and Anderson, 1988). Therefore, it will be more suitable to use PLSSEM to test research hypothesis number Two.

\section{Results and Implications:}

The following section represents the results of statistical analysis and future research and implications.

\subsection{Results of Statistical Analysis:}

The researcher demonstrates the results of statistical analysis as follows;

\subsubsection{Means and Standard Deviations:}

Table No (6) shows Means and Standard Deviations for each independent and dependent variable in this research.

Table (6) Means and standard deviations

\begin{tabular}{|l|c|c|}
\hline Variables & Mean & Std. Deviation \\
\hline \multicolumn{3}{|l|}{ Independent (Sources of formal power) } \\
\hline LEGP & 3.82 & 0.97 \\
\hline REWP & 3.67 & 0.93 \\
\hline COEP & 3.20 & 0.98 \\
\hline Dependent (OBM) & 3.84 & 0.96 \\
\hline SHAR & 3.61 & 0.97 \\
\hline TRAI & 3.69 & 0.94 \\
\hline EMPO & 3.32 & 1.03 \\
\hline REWA & &
\end{tabular}

Source: statistical analysis output.

As table (6) shows, the highest means in the independent variable is 3.82 for Legitimate power and the lowest one is 3.20 for Coercive power. 
Youssef, M. R.Z.; El- Naggar, Soliman, D. M. G

Also, the means for each independent variable in formal sources of power are more than 3 and less than 4. means that according to the opinions of employees in special centers and units, formal sources of power are moderately practiced in these centers and units. Moreover, the highest mean in dependent variables is 3.84 for Sharing information and lowest one is 3.32 for Rewarding. Also, the means for each dependent variable in OBM are more than 3 and less than 4. This also means that practicing OBM in special centers and units is Moderate. In addition, Standard Deviations showed that there is no difference between the opinions of employees in private centers and units concerning the variables of formal sources of power and OBM Therefore, the researcher is seeking to increase the percentage of practicing these variables at special centers and units in this research.

\subsubsection{Test Hypotheses:}

The next table indicates the correlation matrix between sources of power and OBM practices:

Table (7) Multi-correlation Matrix for the relationship between Sources of power and OBM practices

\begin{tabular}{|l|l|l|l|l|l|l|l|}
\hline Variable & LEGP & REWP & COEP & SHAR & TRAI & EMPO & REWA \\
\hline LEGP & 1 & & & & & & \\
\hline REWP & $.685^{* *}$ & 1 & & & & & \\
\hline COEP & $.244^{* *}$ & $.239^{* *}$ & 1 & & & & \\
\hline SHAR & $.798^{* *}$ & $.713^{* *}$ & $-.164^{* *}$ & 1 & & & \\
\hline TRAI & $.669^{* *}$ & $.676^{* *}$ & $-.233^{* *}$ & $.751^{* *}$ & 1 & & \\
\hline EMPO & $.766^{* *}$ & $.721^{* *}$ & $-.207^{* *}$ & $.844^{* *}$ & $.767^{* *}$ & 1 & \\
\hline REWA & $.626^{* *}$ & $.671^{* *}$ & $-.235^{* *}$ & $.674^{* *}$ & $.720^{* *}$ & $.800^{* *}$ & 1 \\
\hline
\end{tabular}

**. Correlation is significant at the 0.01 level.

Source: statistical analysis output.

The first main hypothesis (H1) investigates the direct relationship between formal sources of power (Legitimate, Reward, And Coercive) and OBM practices in special centers and units at Mansoura University, it has been formulated as follows: 
Scientific Journal for Financial and Commercial Studies and Researches

(SJFCSR) Faculty of Commerce - Damietta University

H1. Formal sources of power have a significant correlation with OBM practices. This hypothesis divided to the following subhypotheses;

H1.1. Legitimate power has a significant positive correlation with OBM practices.

H1.2. Reward power has a significant positive correlation with OBM practices.

H1.3. Coercive power has a significant negative correlation with OBM practices.

Table (8) summarize the correlation factors between Formal sources of power and OBM practices:

Table (8) Correlation factors between Formal sources of power and OBM practices

\begin{tabular}{|c|l|l|l|}
\hline OBMp & LEGP & REWP & COEP \\
\hline SHAR & $.798^{* *}$ & $.713^{* *}$ & $-.164^{* *}$ \\
\hline TRAI & $.669^{* *}$ & $.676^{* *}$ & $-.233^{* * *}$ \\
\hline EMPO & $.766^{* *}$ & $.721^{* *}$ & $-.207^{* *}$ \\
\hline REWA & $.626^{* *}$ & $.671^{* *}$ & $-.235^{* *}$ \\
\hline
\end{tabular}

**. Correlation is significant at the 0.01 level.

Source: statistical analysis output.

Analysis of results as shown in table (8) indicates that: there is significant correlation between Formal sources of power and OBM practices which includes sharing information, training employees, empowering employees, and rewarding. All correlation factors are significant at 0.01 level.

Concerning to sub-hypothesis H1.1. Legitimate power has a significant positive correlation with OBM practices. The correlation factors between Legitimate power and OBM practices are $(.798, .669$, $.766, .626)$ which are significant at 0.01 level. That means increasing legitimate power leads to increasing all practices of OBM. Moreover, increasing OBM practices lead to increasing legitimate power. Therefore, hypothesis H1.1. is strongly supported, considering the statistical findings it can be said that the ability of manager to specify tasks to his followers, practice formal authority to commit his employees accomplish 
Youssef, M. R.Z.; El- Naggar, Soliman, D. M. G

their goals and carry their responsibilities lead to, supplying accurate financial and non-financial information on time, providing continuous and required suitable training programs to improve employees' performance, developing financial indicators, participating in making decisions, growing mutual trust and coordination, working independently, Furthermore, increasing legitimate power led to justice in reward system by matching rewards with given efforts, experience, and performance rate, Results in gaining respect. And vice versa.

Concerning to sub-hypothesis H1.2. Reward power has a significant positive correlation with OBM practices. The correlation factors between reward power and OBM practices are $(.713, .676, .721$, $.671)$ which are significant at 0.01 level. That means increasing reward power leads to increasing all practices of OBM. Moreover, increasing OBM practices lead to increasing reward power. Therefore, hypothesis H1.2. is strongly supported. considering the statistical findings, it can be said that managers' ability to make his employees feel important, increase their pay levels, influence their promotions, and supply special benefits led to successfully sharing information, training, empowering, and rewarding employees. At the same time, progressing OBM practices also results in improving managers' Reward power.

Concerning sub-hypothesis H1.3. Coercive power has a significant negative correlation with $\mathrm{OBM}$ practices. The correlation factors between coercive power and OBM practices are (-.164, -.233, $-.207,-.235)$ which are significant at 0.01 level. That means increasing coercive power leads to decreasing all practices of OBM. Moreover, increasing OBM practices lead to decreasing coercive power. Therefore, hypothesis H1.3. is strongly supported. considering the statistical findings, it can be said that managers' ability to force his employees doing their duties, assign undesirable tasks, administer sanctions and punishments to his employees led to shortage in sharing information between managerial levels, neglecting training programs, and decreasing both empowering and rewarding processes.

According to the previous statistical results, the main hypothesis $\mathrm{H1}$ is strongly supported. Taking in account these findings it can be said that increasing formal sources of power (except coercive power) results in increasing OBM practices. These 
Scientific Journal for Financial and Commercial Studies and Researches

(SJFCSR) Faculty of Commerce - Damietta University

results are consistent with the study of (Elangovan and Lin Xie, 2000) which revealed that there is positive correlation between subordinate's satisfaction and both reward and legitimate power. Furthermore, (Elangovan and Lin Xie, 2000) resulted that perceived legitimate and reward power of a supervisor positively related to subordinates' work motivation, while coercive power of the supervisor negatively related to subordinates' work motivation. Also, (Jain et al., 2011) study consisted that reward power has been associated with positive outcomes. While (Chen et al, 2015) found that using coercive power decreases motivation.

The second main hypothesis (H2) examines the impact of formal sources of power on OBM practices in special centers and units at Mansoura University, it has been stated as follows:

H2. Formal sources of power have a significant direct impact on OBM practices. This hypothesis divided into the following subhypotheses;

H2.1. Legitimate power has a significant direct positive impact on OBM practices.

$\mathrm{H} 2.2$. Reward power has a significant direct positive impact on OBM practices.

H2.3. Coercive power has a significant direct negative impact on OBM practices.

Table (9) indicate Path Coefficients for the effects of formal sources of power on OBM practices:

Table (9) Path Coefficients for the effects of formal sources of power on OBM practices

\begin{tabular}{|c|c|c|c|c|c|c|}
\hline OBM & LEGP & P-Value & REWP & P-Value & COEP & P-Value \\
\hline SHAR & 0.241 & $<0.001$ & 0.117 & $<0.001$ & -0.057 & 0.053 \\
\hline TRAI & 0.231 & $<0.001$ & 0.322 & $<0.001$ & -0.104 & 0.002 \\
\hline EMPO & 0.198 & $<0.001$ & 0.214 & $<0.001$ & -0.004 & 0.459 \\
\hline REWA & 0.077 & 0.015 & 0.345 & $<0.001$ & -0.088 & 0.006 \\
\hline OBM & 0.213 & $<0.001$ & 0.28 & $<0.001$ & -0.026 & 0.232 \\
\hline
\end{tabular}

Source: statistical analysis output. 
Youssef, M. R.Z.; El- Naggar, Soliman, D. M. G

Concerning sub-hypothesis H2.1. "Legitimate power has a significant direct positive impact on OBM practices" where the impact coefficient is 0.213 and it is significant at 0.01 level. Therefore, H2.1. is strongly supported. Also, table (9) indicate the effect of Legitimate power on each practice of OBM which show direct significant effect on OBM practices. All coefficients are significant at 0.01 level as shown in $\mathrm{P}$-Value column in the table. The highest coefficient is 0.241 for sharing information variable, while the lowest one is 0.077 for Rewarding variable. That means that increasing Legitimate power led to increase each practice of OBM and OBM as total. Figure (1.2.) summarizes the previous results.

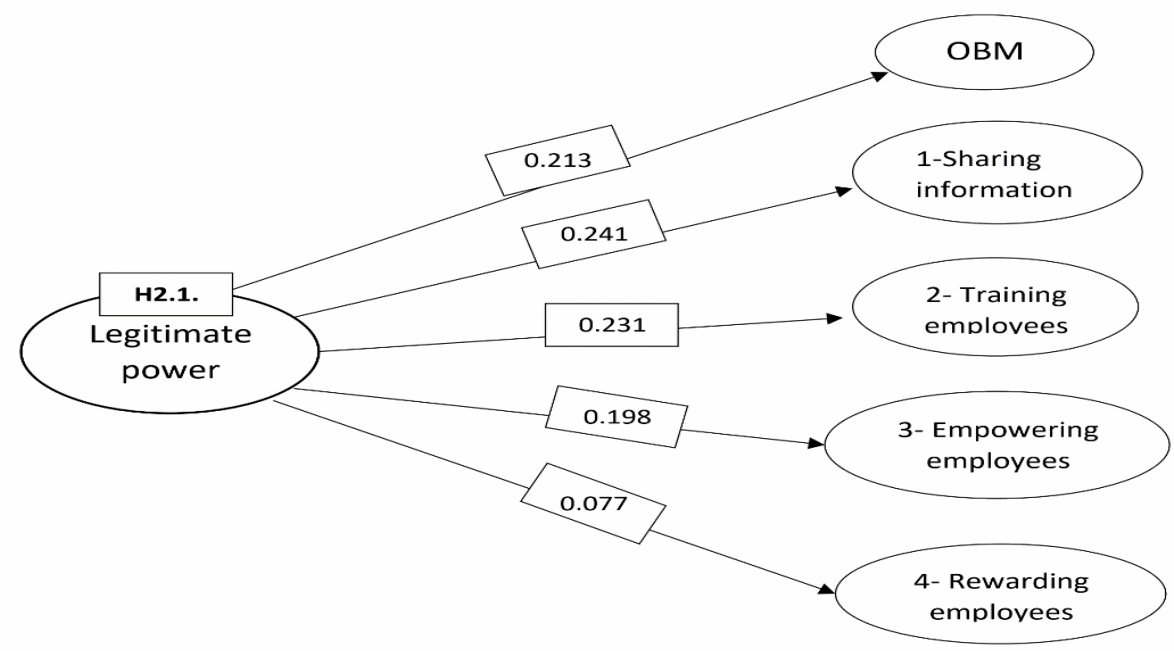

FIGURE 1.2. LEGITIMATE POWER ANALYSIS

Source: Made by the researcher.

Concerning sub-hypothesis H2.2. "Reward power has a significant direct positive impact on OBM practices" where the impact coefficient is 0.28 and it is significant at 0.01 level. Therefore, H2.2. is strongly supported. Also, table (1-8) indicate the effect of reward power on each practice of OBM which show direct significant positive effect on OBM practices. All coefficients are significant at 0.01 level as shown in P-Value column in the table. The highest coefficient is 0.345 for rewarding variable and the lowest one is 0.117 for sharing information 
variable. That means that increasing reward power led to increase each practice of OBM and OBM as total. Figure (1.3.) summarizes the previous results.

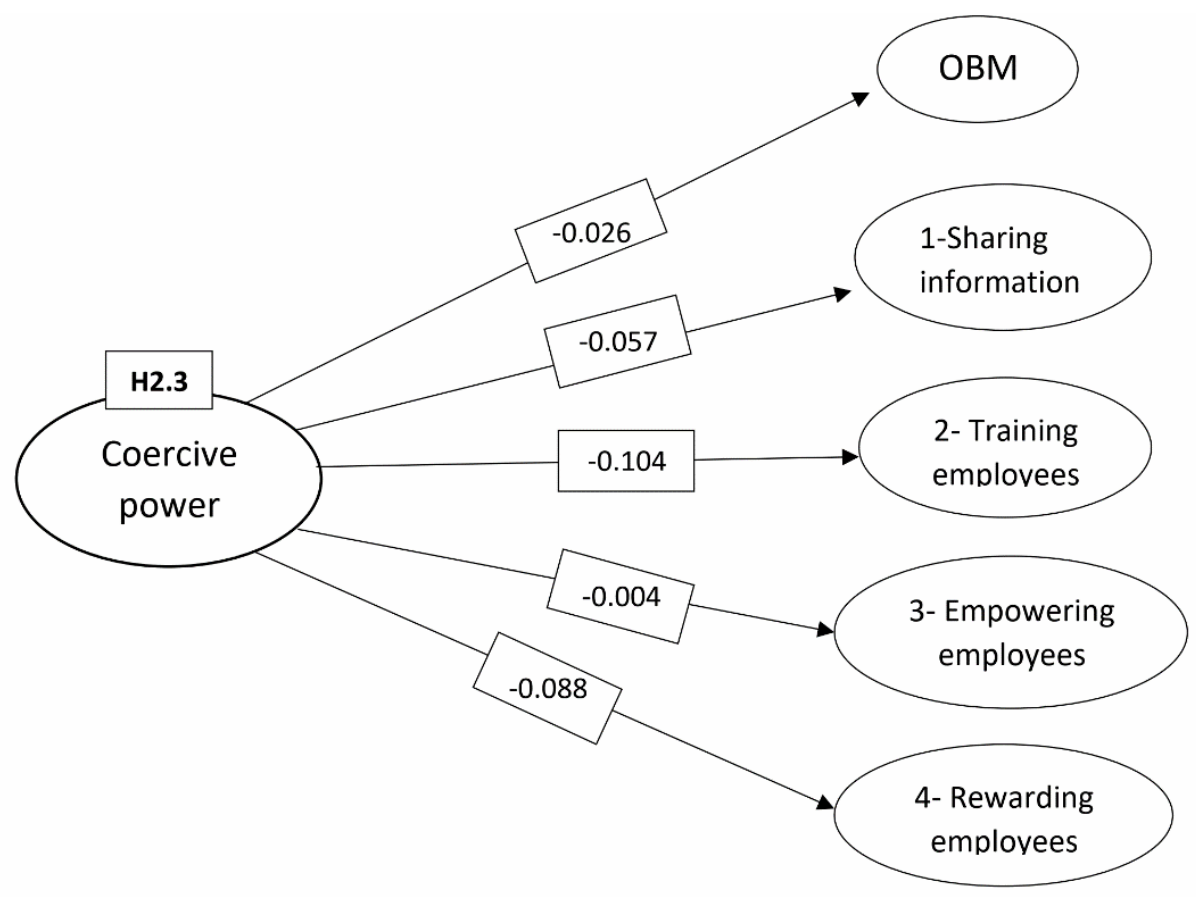

FIGURE 1.4. COERCIVE POWER ANALYSIS

Source: Made by the researcher.

Concerning sub-hypothesis H2.3. "Coercive power has a significant direct negative impact on OBM practices" where the impact coefficient is -0.026 and it is significant at 0.232 level. Therefore, H2.3. is strongly supported. Also, table (1-8) indicate the effect of Coercive power on each practice of OBM which show direct significant negative effect for coercive power on OBM practices. The highest coefficient is -0.104 at significant level 0.002 for training variable and the lowest one is -0.057 at significant level 0.053 for sharing information variable. That means that increasing Coercive power led to decrease each practice of OBM and OBM as total. That negative impact reflects employees' unacceptance for sharing information, training, empowering and rewarding guidelines 
Youssef, M. R.Z.; El- Naggar, Soliman, D. M. G

presented from their managers while using coercive power. Figure (1.4.) summarizes the previous results.

According to the previous statistical results, the main hypothesis $\mathrm{H} 2$ is strongly supported. Taking in account these findings it can be said that increasing Formal sources of power (except coercive power) results in increasing OBM practices. These results are consistent with studies which indicated that formal power impacted knowledge sharing due to (Cai et al, 2013). Also, Reward power had a very strong influence on both trust and motivation. while legitimate power influenced trust directly and motivation through trust according to (Håvold and Håvold, 2019). Hence, (Raven, 2008) concluded that reward power had a strong positive effect on subordinate's satisfaction. Others argue that not only reward power had an influence on satisfaction, but also other formal power bases.

The negative impact for coercive power on OBM practices showed in the results in that research is consistent with the study by (Podsakoff and Schriescheim, 1985) which revealed that coercive power and its use often result in a negative relationship between leader and follower. Also, the effect of coercive power was negative in terms of causing dislike for the teacher and reducing both the cognitive and affective learning of the students according to (Richmond, 1990), In addition, (Elangovan and Lin Xie, 2000) found that perceived coercive power of the supervisor is negatively related to subordinates' work motivation.(Håvold and Håvold, 2019) research also indicate that leaders should be careful in using coercive power.

From the previous results the researcher can conclude the impact of sources of formal power on OBM as a total and rank them in table (10) the following: 
Scientific Journal for Financial and Commercial Studies and Researches

(SJFCSR) Faculty of Commerce - Damietta University

Table (10) the impact of formal sources of power on OBM as a total and its rank

\begin{tabular}{|c|c|c|c|}
\hline Sources of power & B for OBM & P-Value & Rank \\
\hline LEGP & 0.213 & $<0.001$ & 2 \\
\hline REWP & 0.280 & $<0.001$ & 1 \\
\hline COEP & -0.026 & 0.232 & 3 \\
\hline
\end{tabular}

Source: Made by the researcher.

From the previous table the researcher concluded that reward power had the most impact on OBM where its impact coefficient is $(0.280)$ followed by legitimate power with $(0.213)$ and finally coercive power which had negative impact coefficient on OBM (- 0.026).

According to the researcher point of view, reward power is the most one that impacts OBM because giving rewards to employees leads to improving motivation, performance, sharing information, efficient vertical and horizontal relationships and giving more efforts in order to acquire these rewards.

On the other hand, coercive power is considered the least one that impacts OBM where overusing it leads to decreasing employees' spirits, reducing relations and interactions with managers, and sometimes leads to setting obstacles concerned with individuals and groups performance.

\subsection{Summary of research findings:}

Research findings revealed the first main hypothesis $(\mathrm{H} 1)$ which examines the correlation between Formal sources of power (Legitimate, Reward, And Coercive) and OBM practices in special centers and units at Mansoura University was supported, additionally concerning the three sub-hypotheses that are related to the first main hypothesis the statistical analysis indicated the following results: 
Youssef, M. R.Z.; El- Naggar, Soliman, D. M. G

- Legitimate power (H1.1) has a statistically significant positive correlation with OBM practices in Mansoura University special centers and units.

- Reward power (H1.2) has a statistically significant positive correlation with OBM practices in special centers and units at Mansoura University.

- Coercive power (H1.3) has a statistically significant negative correlation with OBM practices in special centers and units at Mansoura University.

With respect to the second main hypothesis $\left(\mathrm{H}_{2}\right)$ which assumes the impact of Formal sources of power on OBM practices in special centers and units at Mansoura University. the results indicated that this main hypothesis was strongly supported. Moreover, the statistical results revealed that the three sub-hypotheses included under this third main hypothesis are strongly supported as follows:

- Legitimate power (H2.1) has a statistically significant direct positive impact on OBM practices in special centers and units at Mansoura University.

- Reward power (H2.2) has a statistically significant direct positive impact on OBM practices in special centers and units at Mansoura University.

- Coercive power (H2.3) has a statistically significant direct negative impact on OBM practices as a whole.

\subsection{The study's Limitations and Implications:}

In this part, the study's limitations are presented. Also, both theoretical and practical implications of this study are discussed, in addition to recommendations for future researches.

\subsubsection{Study's Limitations:}

This research limited only to 25 special centers and units at Mansoura University since the researcher excluded Mansoura university Hospitals due to its private conditions. In addition to centers and units that has no significant contribution in financing Mansoura University. 
Scientific Journal for Financial and Commercial Studies and Researches

(SJFCSR) Faculty of Commerce - Damietta University

The researcher focused on permanent employees who are occupying specialized jobs and have a length of service more than three years since they are the most capable ones to assess the situation of the targeted centers and units.

\subsubsection{Theoretical implications:}

This study strives to contribute to the body of knowledge on managers formal sources of power and OBM practices. In this regard the study makes a number of theoretical and academic contributions by integrating new streams of research that have not been examined previously and addressing some of research gaps in formal sources of power and OBM practices.

First, this study revealed direct positive correlation between legitimate and reward sources of power with OBM practices and also revealed direct negative correlation between coercive power with OBM practices, so, increasing legitimate and reward sources of power leads to increasing OBM practices while increasing coercive power decreases OBM practices.

These relationships have not been sufficiently tested in previous studies, so this study provides a start that contributes to the literature of both leadership sources of power and OBM practices.

Second, this study additionally indicated that formal sources of power had a significant direct effect on OBM practices. Specifically, the study found a significant positive direct impact for legitimate and reward sources of power on OBM practices where coercive power had a significant negative impact on OBM practices. These results contribute to the literature by highlighting the dimensions of formal sources of power that predict OBM practices.

According to the previous results, this study opened a new window for other researchers to research in the field of both leaders' formal power and OBM philosophy.

\subsubsection{Practical implications:}

Based on the results of the field study, a set of practical implications have been provided to help managers at special centers and units in Mansoura University to get benefited from the results of this study. 
Youssef, M. R.Z.; El- Naggar, Soliman, D. M. G

First, implications for formal sources of power:

- Improving the process of selecting and recruiting the managers of special centers and units depending on advertising and selecting managers with high experience, vision, charisma in dealing with profitable organizations and have knowledge about internal and external environment of the university.

- Preventing duplication of authority in special centers and units by making the employees followed directly to the manager.

- Empowering the managers of special centers and units to provide various kinds of performance-contingent rewards and punishments to their subordinates. This can be done by granting the managers formal authority they need to manage the unit affairs, in order to use this power effectively, the managers will require appropriate training.

- Managers can increase their formal power if they follow ethical behaviors with subordinates, policies and procedures consistently, and provide instructions, guidance and advice unambiguously. This require specialized training to give that are rightful considered by their subordinates. Managers should also be encouraged to enhance their communication skills, continuous self-learning, they may also need appropriate job experience to build trust with their subordinates.

- Building formal sources of power requires efficiency, emotional competency skills and human relation training obtained by managers, so that they learn to be empathetic to their subordinates, Interest to their needs and feelings, treat them fairly and ethically, and present their desires to higher level managers when there is a need to do so.

Second, implications for applying OBM;

In light of the study findings, the researcher believes that it is necessary to reconsider the management style currently applied in special centers and units, starting with the development, improvement and updating of all administrative systems and adopting a management 
Scientific Journal for Financial and Commercial Studies and Researches

(SJFCSR) Faculty of Commerce - Damietta University

style based on disclosure, transparency and clarity, which are inherent in the OBM approach. Therefore, the study recommends the following:

- Start OBM with managers first. For example, make certain that managers understand what assets, liabilities, and another key financial variables are and how it relates to the relative profitability of their area. If managers are not convinced of the value of OBM, it will be much difficult to involve lower-level employees in the concept. Additionally, once managers are trained in OBM, they will be key players in disseminating information to their subordinates.

- Providing degrees of empowerment and freedom of action at work for employees and pursuing democracy at work to nurture freedom and release creative energies in special centers and units. Empowerment should not be on a hierarchal basis but rather based on efficiency and enhanced performance.

- Showing transparency and openness in the flow of information between members of administrative management and getting rid of the culture of hoarding information. where open communication and permanent diversification of communication channels should be met, so that barriers disappear between the head and the subordinates. There is also a need to hold brainstorming sessions and meetings to stimulate creative thinking and share experiences.

- Workers should participate in the center's decision making and they should be looked on as stakeholders in the decision-making process and in university development. Also, skilled staff members should be considered as the university's capital not a burden.

- Encouraging the spirit of initiative and innovation, and Establishing the principle of credibility by strengthening mutual trust between managers and workers at special centers and units.

- Setting a scenario to activate the budget in a correct way, where all employees in special centers and units contribute to so that they have a true sense of ownership. This will boost employee levels of belonging and loyalty. In addition, All the numbers in units should 
Youssef, M. R.Z.; El- Naggar, Soliman, D. M. G

be visible to units' workers. This helps in proposing ideas that will move these numbers up in favor of Mansoura university.

- Adoption of a reward system, linking it to performance, excellence, creativity, and innovation.

\subsubsection{Recommendations for Future Research:}

Based on the study results, the following recommendations are for future research:

1. Studying the relationship between supervisors' formal power and conflict management style.

2. Investigating the effect of formal sources of power on managing ethical crises.

3. Mediating OBM in the relationship between managers formal sources of power and job performance.

4. Studying the impact of formal sources of power on decision making process through OBM as a mediating variable.

5. Investigating the relationship between OBM and both employee job performance and customer satisfaction.

6. Replicating the current study in other industries outside learning institutions.

\section{References}

1. Abdulkarim Alkhamis, F. 2018. The mediating role of employee job performance in the impact of open book management dimensions on customer satisfaction. Business: Theory and Practice, 19: (0), 157-165.

2. Afzalur Rahim, M., Antonioni, D. \& Psenicka, C. 2001. A structural equations model of leader power, subordinates' styles of handling conflict, and job performance. International Journal of Conflict Management, 12: (3), 191-211.

3. Agbaeze, E. K., \& Nnaji, P. A. 2017. Evaluation of the impact of Open Book Management on employee performance in selected manufacturing firms in Enugu State, Nigeria. Preface and acknowledgements, 116. 
Scientific Journal for Financial and Commercial Studies and Researches

(SJFCSR) Faculty of Commerce - Damietta University

4. Aggarwal, R. \& Simkins, B. J. 2001. Open book managementoptimizing human capital. Business Horizons, 44: (5), 5-13.

5. Aggarwal, R. \& Simkins, B. J. 2001. Open book managementoptimizing human capital. Business Horizons, 44: (5), 5-13.

6. Al- Sha'ar, H. 2016. The Impact of Open Book Management on Achieving Differentiation in the Business Organization. International Journal of Human Resource Studies, 6: (2), 223.

7. Alapo, R. 2018. Organizational power politics and leadership experiences on the view and use of power in organizations. Management Accounting Research, 6: (1), 30-36.

8. Al-Awadi NA 2005. A proposed model for open-book management approach to achieve effective change through application on the Ministry of Health in the United Arab Emirates. PhD Thesis, Ain Shams University, Egypt.

9. Al-Harahsheh, M., Kingman, S., \& Bradshaw, S. 2006. The reality of non-thermal effects in microwave assisted leaching systems?. Hydrometallurgy, 84(1-2), 1-13.

10. Al-Khatib, M. M. 2018. Strategic Awareness and its Impact on Strategic Risks the Moderating role of Open Book Management Practices (OBMp) A Field Study on the Fuel Distributer Companies in Jordan. Unpublished Master Thesis in Business Management, Department of Management, Faculty of Business, Middle East University, Amman, Jordon.

11. Al-Mekhalfi, A. 2008. Leadership style of the public and private secondary schools principals in San'a City for the teacher's point of view and their relation with occupational satisfaction. unpublished master theses, Arab Amman University, AmmanJordan.

12. Al-Mekhlafi, M. H., Surin, J., Atiya, A. S., Ariffin, W. A., Mahdy, A. M., \& Abdullah, H. C. 2008. Pattern and predictors of soil-transmitted helminth reinfection among aboriginal 
Youssef, M. R.Z.; El- Naggar, Soliman, D. M. G

\begin{tabular}{l}
\hline \hline schoolchildren in rural Peninsular \\
Tropica, 107(2), 200-204.
\end{tabular}

13. Al-Mutairi, A. 2013. Role of open-book management on employees increased job satisfaction: Application on the Kuwait Oil Company. Journal of Thought and Creativity, 74: 609-636.

14. Broughton, A. C. \& Thomas, J. 2012. Embracing Open-Book Management to Fuel Employee Engagement and Corporate Sustainability. White paper. University of North Carolina, KenanFlagler Business School.

15. Buhler, P. M. 2010. Opening up management communication: Learning from open-book management. Supervision, 71: (8), 1517.

16. Campbell, D., Dopico, L., Fotsch, B. \& Case, J. 2018. The Practice of Open-Book Management in Credit Unions. Journal of Personality and Social Psychology, 71 (5): 12-17.

17. Carl, D., Gupta, V. and Javidan, M. 2004, "Power distance", in House, R.J., Hanges, P.J., Javidan, M., Dorfman, P.W. and Gupta, V. (Eds), Culture, Leadership, and Organizations. The GLOBE Study of Society, Sage, Thousand Oaks, CA, pp. 513563.

18. Case, J. 1996. Open-Book Management: Coming Business Revolution, The. Harp

19. Case, J. 1998. The open-book experience: Lessons from over 100 companies who successfully transformed themselves. Basic Books.

20. Chen, W., Wu, Y., Yue, Y., Liu, J., Zhang, W., Yang, X., ... \& Han, L. 2015. Efficient and stable large-area perovskite solar cells with inorganic charge extraction layers. Science, 350(6263), 944-948. 
Scientific Journal for Financial and Commercial Studies and Researches

(SJFCSR) Faculty of Commerce - Damietta University

21. Elangovan, A. R. \& Lin Xie, J. 2000. Effects of perceived power of supervisor on subordinate work attitudes. Leadership \& Organization Development Journal, 21: (6), 319-328.

22. Elias, S. M. 2007. Influence in the Ivory Tower: Examining the Appropriate Use of Social Power in the University Classroom. Journal of Applied Social Psychology, 37: (11), 2532-2548.

23. Erkutlu, H., Chafra, J., \& Bumin, B. 2011. Organizational culture's role in the relationship between power bases and job stress. Hacettepe University Journal of Education, 40, 198-209.

24. Fairholm, G. W. 2009. Organizational power politics: tactics in organizational leadership, ABC-CLIO.

25. Fielding, N. G., Lee, R. M., \& Blank, G. (Eds.). 2008. The $S A G E$ handbook of online research methods. Sage.

26. French, J. R., Raven, B. \& Cartwright, D. 1959. The bases of social power. Classics of organization theory, 7: 311-320.

27. French, R., Rayner, C., Rees, G. \& Rumbles, S. 2016. Organizational Behaviour.

28. Gerbing, D. W. \& Anderson, J. C. 1988. An Updated Paradigm for Scale Development Incorporating Unidimensionality and Its Assessment. Journal of Marketing Research, 25: (2), 186.

29. Greve, H. R. \& Mitsuhashi, H. 2007. Power and Glory: Concentrated Power in Top Management Teams. Organization Studies, 28: (8), 1197-1221.

30. Guinote, A. 2008. Power and affordances: When the situation has more power over powerful than powerless individuals. Journal of Personality and Social Psychology, 95(2), 237.

31. Gupta, B. and Sharam, N. K. 2008. Compliance with base of power and subordinates' Perception of superiors: Moderating effect of quality of interaction. Singapore Management Review, $30,1,1-24$. 
Youssef, M. R.Z.; El- Naggar, Soliman, D. M. G

32. Hadiyan, M. 2000. Study of manager's power sources and its relationship with effectiveness on views teachers, Dissertation MA, University of Tehran.

33. Håvold, J. I. \& Håvold, O. K. 2019. Power, trust and motivation in hospitals. Leadership in Health Services, 32: (2), 195-211.

34. Håvold, J. I., \& Nesset, E. 2009. From safety culture to safety orientation: validation and simplification of a safety orientation scale using a sample of seafarers working for Norwegian ship owners. Safety Science, 47(3), 305-326.

35. Heale, R. \& Twycross, A. 2015. Validity and reliability in quantitative studies. Evidence Based Nursing, 18: (3), 66-67.

36. Hinkin, T. R., \& Schriesheim, C. A. 1989. Development and application of new scales to measure the French and Raven (1959) bases of social power. Journal of applied psychology, 74(4), 561.

37. Ismael, N. F. 2018. Open-book management in libraries: A case study of Bibliotheca Alexandrina. IFLA Journal, 44: (4), 323339.

38. Kantek, F. \& Gezer, N. 2006. Responsible nurses' power usage. Journal of Business Studies, 10: 37-40.

39. Kantek, F. \& Gezer, N. 2010. Faculty members' use of power: midwifery students' perceptions and expectations. Midwifery, 26: (4), 475-479.

40. Kidwell, R. E. \& Scherer, P. M. 2001. Layoffs and their ethical implications under scientific management, quality management and open-book management. Journal of Business Ethics, 29: (1), 113-124.

41. Kinney, M., \& Raiborn, C. 2008. Cost accounting: Foundations and evolutions. Cengage Learning. 
Scientific Journal for Financial and Commercial Studies and Researches

(SJFCSR) Faculty of Commerce - Damietta University

42. Malhotra, D., \& Bazerman, M. 2007. Negotiation genius: How to overcome obstacles and achieve brilliant results at the bargaining table and beyond. Bantam.

43. Mastenbroek, W. 2005. Organizational behavior in historical perspective: Part 2: Emotion management, status competition and power play. Management Site.

44. Matar AE, 2008 Open-book management as an entry to develop performance at Practical Education and Field Training Office in the Faculty of Basic Education. Journal of Sports as Science and Art 30: 375-397.

45. Maurer, R. 2001. Open-book management. The Journal for Quality and Participation, 24(1), 64.

46. Melhem, Y. 2006. Empowerment as a contemporary management concept. Cairo: Arab Organization for Administrative Development.

47. Meng, Y., He, J. \& Luo, C. 2014. Science Research Group Leader's Power and Members' Compliance and Satisfaction with Supervision. Research Management Review, 20: (1), n1.

48. Merchant, C. 2013. Reinventing Eden: The fate of nature in Western culture. Routledge.

49. Negron, A. 1997. Open book management goes beyond the bottom line. Massachusetts Institute of Technology.

50. Nikzad, M. \& Maryam, G. 2012. The relationship between open book management and trust with organization financial performance. Procedia Technology, 1: 340-344.

51. Pitesa, M., \& Thau, S. 2013. Compliant sinners, obstinate saints: How power and self-focus determine the effectiveness of social influences in ethical decision making. Academy of Management Journal, 56(3), 635-658.

52. Rahim, M. A., \& Psenicka, C. 1996. Bases of leader power, workgroup commitment, and conflict: A structural equations 
Youssef, M. R.Z.; El- Naggar, Soliman, D. M. G

model. In M. A. Rahim, R. T. Golembiewski, \& C. C. Lundberg (Eds.), Current topics in management (Vol. 1, pp. 31-47). Greenwich, CT: JAI Press.

53. Randolph, W. A. \& Kemery, E. R. 2011. Managerial use of power bases in a model of managerial empowerment practices and employee psychological empowerment. Journal of Leadership Organizational Studies, 18: (1), 95-106.

54. Riasi, A. \& Asadzadeh, N. 2015. The relationship between principals' reward power and their conflict management styles based on Thomas-Kilmann conflict mode instrument. Management Science Letters, 5: (6), 611-618.

55. Riasi, A. \& Asadzadeh, N. 2016. How coercive and legitimate power relate to different conflict management styles: a case study of Birjand high schools. Journal of Studies in Education, 6: (1), 147-159.

56. Rossiter, J. R. 2008. Content Validity of Measures of Abstract Constructs in Management and Organizational Research. British Journal of Management, 19: (4), 380-388.

57. Salem MA, Hussein $S$ and Mansour M 2012 Improving management performance of technical high school using the strategy of open-book management. Faculty of Educa2on Journal 23(90): $323-312$.

58. Saunders, M. N. K., Lewis, P. \& Thornhill, A. 2015. Research Methods for Business Students, Pearson Education Limited.

59. Schuster, J. P., Carpenter, J. \& Kane, P. 1996. The power of open-book management: Releasing the true potential of people's minds, hearts, and hands, University of Texas Press.

60. Singh, R., Seshadri, D. V. R., Kumra, R., Agndal, H., \& Nilsson, U. 2012. Open book practices in buyer-supplier relationships in India. Journal of Business \& Industrial Marketing. 
Scientific Journal for Financial and Commercial Studies and Researches

(SJFCSR) Faculty of Commerce - Damietta University

61. Smith, A., Houghton, S. M., Hood, J. N. \& Ryman, J. A. 2006. Power relationships among top managers: Does top management team power distribution matter for organizational performance? Journal of Business Research, 59: (5), 622-629.

62. Smith, P. K. \& Trope, Y. 2006. You focus on the forest when you're in charge of the trees: Power priming and abstract information processing. Journal of Personality and Social Psychology, 90: (4), 578-596.

63. Solheim, I., Barnard, Y., Storrøsten, M. N., \& Sørhaug, E. 2007. Gevinstanalyse av e-learning.

64. Teimouri, H., Izadpanah, N., Akbariani, S., Jenab, K., Khoury, S. \& Moslehpour, S. 2015. The effect of managerial power on employees' affective commitment: Case study. Journal of Management, 3:(2), 21-30.

65. Turman, P. D., \& Schrodt, P. 2006. Student perceptions of teacher power as a function of perceived teacher confirmation. Communication Education, 55(3), 265-279.

66. Uhl-Bien, M., \& Carsten, M. K. 2007. Being ethical when the boss is not.

67. Uhl-bien, M., Schermerhorn, J. \& N. Osborn, R. 2013. Organizational behavior. 608.

68. Walls, J. L. \& Berrone, P. 2017. The power of one to make a difference: How informal and formal CEO power affect environmental sustainability. Journal of Business Ethics, 145: (2), 293-308.

69. Yang, Y., Gupta, M. C., Dudley, K. L., \& Lawrence, R. W. 2005. Novel carbon nanotube- polystyrene foam composites for electromagnetic interference shielding. Nano letters, 5(11), 21312134.

70. Yilmaz, K., Altinkurt, Y., \& Cokluk, O. 2011. Developing the Educational Belief Scale: The Validity and Reliability 
Youssef, M. R.Z.; El- Naggar, Soliman, D. M. G

Study. Educational Sciences: Theory and Practice, 11(1), 343350 .

71.Yoon, D. J. \& Farmer, S. M. 2018. Power that builds others and power that breaks: Effects of power and humility on altruism and incivility in female employees. The Journal of Psychology, 152: (1), 1-24.

72.Yukl, G, \& Falbe, C. 1990. Influence tactics and objectives in upward, downward, and lateral relations. Journal of Applied Psychology, 75, 132-140.

73.Yukl, G., \& Falbe, C. M. 1991. Importance of different power sources in downward and lateral relations. Journal of Applied Psychology, 76, 416-423.

74. Zameni, F., Enayati, T. \& Palar, H. 2012. The analysis of the relationship between the managers power resources and organizational commitment: a case study of employees of education organization of mazandaran province.

75. Zhaher $\mathbf{T}$ 2012. The impact of organizational climate of the empowerment of employees. Journal of Damascus University of Economic and Legal Sciences 28(2): 255-282.

76. Zigarmi, D., Roberts, T. P. \& Alan Randolph, W. 2015. Employees' Perceived Use of Leader Power and Implications for Affect and Work Intentions. Human Resource Development Quarterly, 26: (4), 359-384. 
Scientific Journal for Financial and Commercial Studies and Researches

(SJFCSR) Faculty of Commerce - Damietta University

\section{Appendix (A)}

\section{Questionnaire}

\section{Questionnaire Items:}

The following statements are related to the study's constructs, so please read them well, then put the sign $(\sqrt{ })$ for the choice that reflects your opinion by choosing one of the given alternatives, in which the highest acceptable sentence gets (5) reflects totally agree, and the lowest acceptable sentence get (1) reflects totally disagree.

\begin{tabular}{|c|c|c|c|c|c|}
\hline Paragraph & $\begin{array}{l}\text { Totally } \\
\text { Agree } \\
\text { (5) }\end{array}$ & $\begin{array}{c}\text { Agree } \\
\text { (4) }\end{array}$ & $\begin{array}{c}\text { Neutral } \\
\text { (3) }\end{array}$ & $\begin{array}{c}\text { Disagree } \\
\text { (2) }\end{array}$ & $\begin{array}{l}\text { Totally } \\
\text { Disagree } \\
\text { (1) }\end{array}$ \\
\hline $\begin{array}{l}\text { 1. My manager can } \\
\text { make me recognize } \\
\text { that I have tasks to } \\
\text { accomplish. }\end{array}$ & & & & & \\
\hline $\begin{array}{l}\text { 2. My manager has } \\
\text { influencing ability on } \\
\text { the employees in the } \\
\text { unit. }\end{array}$ & & & & & \\
\hline $\begin{array}{l}\text { 3. My managers' } \\
\text { position in the unit } \\
\text { provides him/her with } \\
\text { the authority to direct } \\
\text { their work activities. }\end{array}$ & & & & & \\
\hline $\begin{array}{l}\text { 4. My manager makes } \\
\text { me feel that I have } \\
\text { commitments to meet. }\end{array}$ & & & & & \\
\hline $\begin{array}{l}\text { 5. My manager can give } \\
\text { me the feeling that I } \\
\text { have responsibilities } \\
\text { to fulfill. }\end{array}$ & & & & & \\
\hline $\begin{array}{lll}\text { 6. My manager can } & \text { make me } & \text { feel } \\
\text { mportant. } & \\
\text { impor }\end{array}$ & & & & & \\
\hline $\begin{array}{l}\text { 7. My manager can } \\
\text { increase my pay } \\
\text { levels. }\end{array}$ & & & & & \\
\hline
\end{tabular}


Youssef, M. R.Z.; El- Naggar, Soliman, D. M. G

\begin{tabular}{|c|c|c|c|c|c|}
\hline Paragraph & $\begin{array}{l}\text { Totally } \\
\text { Agree } \\
\text { (5) }\end{array}$ & $\begin{array}{l}\text { Agree } \\
\text { (4) }\end{array}$ & $\begin{array}{c}\text { Neutral } \\
\text { (3) }\end{array}$ & $\begin{array}{l}\text { Disagree } \\
\text { (2) }\end{array}$ & $\begin{array}{c}\text { Totally } \\
\text { Disagree } \\
(1) \\
\end{array}$ \\
\hline $\begin{array}{l}\text { 8. My manager can give } \\
\text { special help and } \\
\text { benefits to those who } \\
\text { cooperate } \\
\text { him/her. }\end{array}$ & & & & & \\
\hline $\begin{array}{l}\text { 9. My manager affects } \\
\text { my promotions in the } \\
\text { unit. }\end{array}$ & & & & & \\
\hline $\begin{array}{l}\text { 10. My manager rewards } \\
\text { good work. }\end{array}$ & & & & & \\
\hline $\begin{array}{l}\text { 11. My manager can give } \\
\text { me undesirable job } \\
\text { assignments. }\end{array}$ & & & & & \\
\hline $\begin{array}{l}\text { 12. My manager can } \\
\text { force the employees to } \\
\text { do their duties and } \\
\text { responsibilities. }\end{array}$ & & & & & \\
\hline $\begin{array}{l}\text { 13. My manager can } \\
\text { make work difficult } \\
\text { for me/ can give hard } \\
\text { tasks to do. }\end{array}$ & & & & & \\
\hline $\begin{array}{l}\text { 14. My manager can } \\
\text { make being at work } \\
\text { distasteful for me/ can } \\
\text { make me hate my } \\
\text { work. }\end{array}$ & & & & & \\
\hline $\begin{array}{l}\text { 15. My manager can } \\
\text { punish those who do } \\
\text { not cooperate with } \\
\text { him/her. }\end{array}$ & & & & & \\
\hline $\begin{array}{l}\text { 16. The employee } \\
\text { receives information } \\
\text { at the needed time } \\
\text { without delay. }\end{array}$ & & & & & \\
\hline $\begin{array}{l}\text { 17. Information issued by } \\
\text { the administration is } \\
\text { accurate and clear. }\end{array}$ & & & & & \\
\hline
\end{tabular}


Scientific Journal for Financial and Commercial Studies and Researches (SJFCSR) Faculty of Commerce - Damietta University

\begin{tabular}{|c|c|c|c|c|c|}
\hline Paragraph & $\begin{array}{l}\text { Totally } \\
\text { Agree } \\
\text { (5) }\end{array}$ & $\begin{array}{c}\text { Agree } \\
\text { (4) }\end{array}$ & $\begin{array}{c}\text { Neutral } \\
\text { (3) }\end{array}$ & $\begin{array}{c}\text { Disagree } \\
\text { (2) }\end{array}$ & $\begin{array}{l}\text { Totally } \\
\text { Disagree } \\
\text { (1) }\end{array}$ \\
\hline $\begin{array}{l}\text { 18. The employee gets } \\
\text { statistical information } \\
\text { without any } \\
\text { constraints. }\end{array}$ & & & & & \\
\hline $\begin{array}{l}\text { 19. There is } \\
\text { confidentiality in } \\
\text { information exchange. }\end{array}$ & & & & & \\
\hline $\begin{array}{l}\text { 20. The manager ensures } \\
\text { that employees are } \\
\text { provided with the } \\
\text { needed feedback } \\
\text { about performance } \\
\text { level each period. }\end{array}$ & & & & & \\
\hline $\begin{array}{l}\text { 21. There is continuous } \\
\text { training and appraisal } \\
\text { tools to assess the } \\
\text { need for employees } \\
\text { training. }\end{array}$ & & & & & \\
\hline $\begin{array}{l}\text { 22. I get a continuous } \\
\text { training to improve } \\
\text { my ability to } \\
\text { understand the unit } \\
\text { work issues. }\end{array}$ & & & & & \\
\hline $\begin{array}{l}\text { 23. I get a continuous } \\
\text { training to improve } \\
\text { my ability to develop } \\
\text { the financial } \\
\text { indicators in the unit. }\end{array}$ & & & & & \\
\hline $\begin{array}{l}\text { 24. There is regular } \\
\text { meetings to discuss } \\
\text { the performance } \\
\text { indicators of the unit. }\end{array}$ & & & & & \\
\hline $\begin{array}{l}\text { 25. The manager } \\
\text { encourages his } \\
\text { employees to training } \\
\text { and self-learning to } \\
\text { achieve organizational } \\
\text { goals. }\end{array}$ & & & & & \\
\hline
\end{tabular}


Youssef, M. R.Z.; El- Naggar, Soliman, D. M. G

\begin{tabular}{|c|c|c|c|c|c|}
\hline Paragraph & $\begin{array}{l}\text { Totally } \\
\text { Agree } \\
\text { (5) }\end{array}$ & $\begin{array}{c}\text { Agree } \\
\text { (4) }\end{array}$ & $\begin{array}{c}\text { Neutral } \\
\text { (3) }\end{array}$ & $\begin{array}{c}\text { Disagree } \\
\text { (2) }\end{array}$ & $\begin{array}{l}\text { Totally } \\
\text { Disagree } \\
\text { (1) }\end{array}$ \\
\hline $\begin{array}{l}\text { 26. All employees } \\
\text { participate in decision } \\
\text { making. }\end{array}$ & & & & & \\
\hline $\begin{array}{l}\text { 27. Management } \\
\text { enhances the climate } \\
\text { of trust with workers. }\end{array}$ & & & & & \\
\hline $\begin{array}{l}\text { 28. Employees are given } \\
\text { more authority and } \\
\text { freedom of action in } \\
\text { handling their own } \\
\text { work. }\end{array}$ & & & & & \\
\hline $\begin{array}{l}\text { 29. There is integration } \\
\text { and coordination } \\
\text { between the different } \\
\text { managerial levels at } \\
\text { all centers and units. }\end{array}$ & & & & & \\
\hline $\begin{array}{l}\text { 30. I take responsibility } \\
\text { for all my business } \\
\text { decisions. }\end{array}$ & & & & & \\
\hline $\begin{array}{l}\text { 31. What I get from the } \\
\text { job fits with my effort. }\end{array}$ & & & & & \\
\hline $\begin{array}{l}\text { 32. The income I get } \\
\text { from my job fits with } \\
\text { my colleagues' } \\
\text { income in other } \\
\text { special units. }\end{array}$ & & & & & \\
\hline $\begin{array}{l}\text { 33. The income I get } \\
\text { from my work fits } \\
\text { with my experience. }\end{array}$ & & & & & \\
\hline $\begin{array}{l}\text { 34. With every special } \\
\text { work done by me, I } \\
\text { get the appreciation } \\
\text { and respect from my } \\
\text { manager. }\end{array}$ & & & & & \\
\hline $\begin{array}{l}\text { 35. I take responsibility } \\
\text { for any mistake I } \\
\text { make } \\
\text { performing my work. }\end{array}$ & & & & & \\
\hline
\end{tabular}

